\title{
ANALISIS PENYALURAN DAN PENGGUNAAN DANA DESA DI DESA LINELEAN KECAMATAN MODOINDING KABUPATEN MINAHASA SELATAN
}

\author{
Pretty A. Langkun ${ }^{1}$, Ventje Ilat ${ }^{2}$, Rudy J. Pusung ${ }^{3}$ \\ 1,2,3 Jurusan Akuntansi, Fakultas Ekonomi dan Bisnis, Universitas Sam Ratulangi, Jl. Kampus Bahu, Manado, \\ 95115, Indonesia
}

Email : Langkunpretty@gmail.com

\begin{abstract}
Village Funds are APBN funds allocated to Villages transferred through district / city APBD and prioritized for the implementation of development and empowerment of rural communities. The granting of village funds is carried out in stages, namely budgeting, allocation, distribution, use, reporting and monitoring / evaluation of Village Funds. This study aims to determine the mechanism of Village Funds Distribution in Linelean village, Modoinding Subdistrict, South Minahasa Regency, and find out the Use of Village Funds in Linelean Village, Modoinding District, South Minahasa Regency. This research method uses descriptive method and the type of research used is descriptive qualitative. The results showed that the Village Fund Distribution in the village of Linelean was in accordance with the Regulations of the South Minahasa Regent and the Use of Village Funds went well.

Keywords: village funds, distribution, use
\end{abstract}

\section{PENDAHULUAN}

Lewat Nawacita pemerintah Indonesia memiliki komitmen dalam mengembangkan Indonesia dari pinggiran, antara lain dengan mendorong pembangunan desa. Dana desa merupakan bentuk penyaluran dari dana pemerintah. Agar mendorong pelaksanaan tugas dan fungsi desa dalam setiap prinsipnya sesuai ketentuan, Undang-undang no 6 tahun 2014 menjelaskan tujuan pada pemerintah agar mengalokasikan dana desa. Dana desa itu dibiayai kesetiap periode kepada Anggara Pendapatan dan Belanja Negara yang memperoleh pada masing-masing desa sebagai suatu pusat pendapatan desa. aturan ini juga sekalian menilaikan dan menyempurnakan setiap jadwal penyaluran anggaran kepada pemerintah kepada setiap desa yang selama ini telah ada. Pembangunan desa ialah wujud nawacita ke 3 Presiden Jokowi, yaitu "membangun indonesia dari pinggiran dengan memperkuat daerah-daerah dan desa dalam kerangka NKRI". Keuangan desa ditunjukan dan desa dikirimkan melalui APBD kabupaten disalurkan untuk segala desa dan adil menyeluruh.

\section{TINJAUAN PUSTAKA}

Pengertian Akuntansi. Penjelasan tentang akuntansi merupakan informasi sangat dibutuhkan oleh pihak-pihak yang berkepentingan dalam hal pengambilan keputusan ekonomi.

Akuntansi Pemerintahan. Akuntansi pemerintahan menurut Riyanto (2015:28) menyatakan akuntansi pemerintahan merupakan suatu kegiatan jasa penyediaan informasi kuantitatif sifatnya keuangan dari entitas pemerintah untuk mengambil keputusan ekonomi dari pihak yang berkepentingan.

Dana Desa. Desa adalah desa dan desa adat atau sebutan lain, seteruanya sebutan desa, merupakan integritas rakyat hukum serta punya batas wilayah berwenang dalam pengaturan dan mengolah tentang pemerintahan, keperluan masyarakat sekitar yang sesuai dengan perintisan masyarakat, sistem pemerintahan NKRI. 
Penyaluran Dana Desa. Penyaluran DD dilaksanakan dari pemerintah pada kabupaten dilaksanakan melalui cara pemindahan buku dari RKUN ke RKUD. Selanjutnya, dana yang ada diberikan pada pemerintah kabupaten ke desa. Penyaluran DD dijalankan melalui tahapan-tahapan dengan periode pembiayaan dan dikerjakan paling lama 7 hari saat terima pada RKUD.

Penggunaan Dana Desa. Peraturan Pemerintah Republik Indonesia No. 60 Tahun 2014 Pasal 18 yaitu Dana Desa dipergunakan untuk pembiayai pelaksanaan pemerintahan, pemberdayaan pembangunan rakyat, serta kemasyarakatan. Penggunaan dana desa mengacu kepada RPJM Desa dan RKPDes. DD diperuntukan dalam membiayai pembangunan dan pemberdayaan masyarakat.

\section{METODE PENELITIAN}

Jenis Penelitian. Kualitatif deskriptif jenis penelitian yang digunakan. Penelitian ini termasuk kualitatif dimana data yang diperoleh digunakan untuk menganalisis.

Tempat dan Waktu Penelitian. Lokasi penelititan dilakukan pada desa Linelean, kecamatan Modoinding, kabupaten Minahasa Selatan. Waktu penelitian adalah Mei sampai September. Proses penelitian ini dapat dilaksanakan dengan persetujuan dari Hukum Tua Desa Linelean Kecamatan Modoinding.

Jenis Data. Jenis data yang digunakan yaitu data kualitatif lewat wawancara dengan subjek penelitian yaitu hukum tua, dan sekertaris desa Linelean kecamatan modoinding. Data kuantitatif dari kantor desa Linelean dalam penulisan skripsi ini, yaitu data kualitatif dalam hal ini berupa prosedur penyaluran dan penggunaan dana desa dan data kuantitatif berupa laporan realisasi anggaran.

Sumber Data. Data primer sumber data ini langsung memberikan data pada pengumpul data. Penulis telah melakukan observasi dan merampulkan data dalam hasil Wawancara, data Penyaluran dan Penggunaan Dana Desa pada kantor Desa Linelean Kecamatan Modoinding kabupaten Minahasa Selatan.

Metode Pengumpulan Data. Wawancara dan dokumentasi.

Metode dan Proses Analisis. Penelitian ini menggunakan metode analisis deskriptif. Penyaluran adalah proses menyalurkan dana dalam Penyaluran Dana Desa di Desa Linelean kecamatan modoinding dan Penggunaan Dana Desa. Metode Penelitian ini menggunakan data kualitatif, dengan wawancara kepada narasumber yang bersangkutan yakni Hukum Tua, dan sekertaris Desa Linelean Kecamatan modoinding. Lalu pertanyaan yang akan ditanyakan mengenai mekanisme penyaluran Dana Desa, dan Penggunaan Dana Desa di Desa Linelean Kecamatan Modoinding, kemudian hasil wawancara tersebut diberi kesimpulan mengenai proses Penyaluran Dana Desa. Kemudian jenis data kuantitatif yang akan diambil berupa laporan keuangan atau laporan realisasi anggaran tahun 2017 data ini digunakan untuk mengetahui penerimaan dan pengeluaran dana desa serta keterangan penggunaan Dana Desa.

\section{HASIL PENELITIAN DAN PEMBAHASAN}

\subsection{Hasil Penelitian}

Mekanisme Penyaluran Dana Desa. Proses pencairan dan penyaluran DD mematuhi keputusan dan tata cara penyaluran APBDesa. Sesuai dengan ketentuan DD disalurkan ke pemerintah desa lewat rekening tiap-tiap desa, selanjutnya Dana Desa (DD) masuk ke dalam Kas Desa dan merupakan tahap pendapatan desa. Sesuai dengan penuturan Hukumtua desa Linelean yaitu Bpk.Rojer Kapahang menurut wawancara dengan kuntua:

"Penyaluran Dana Desa adalah salah satu aspek penting dalam pelaksanaan Dana Desa, pencairan Dana Desa menunggu APBDes Selesai karena syarat utama bagi desa untuk mencairkan Dana Desa dan Alokasi Dana Desa setelah APBDes dari semua desa rampung baru proses pencairan bisa dilakukan. Berbeda dengan ADD yang proses penyalurannya 
secara triwulan, penyaluran DD pada tahun 2017 hanya melalui dua tahap. Penyaluran Dana Desa dari pemerintah ke Desa pertama melalui banyak tahapan yaitu Laporan LPJ,mengajukan proposal dan pengajuan dana di bidang keuangan aset daerah setelah ada persetujuan dari bupati untuk pencairan dana, tanda tangan sepsimen dari Hukum Tua, Sekdes baru bisa dilakukan pencairan dana. (Hasil wawancara dengan Kepala Desa, Pada 08 September 2018)"

Swadaya masyarakat adalah bukti partisipasi di Desa Linelean Kecamatan Modoinding antara lain:

Tabel 1. Data Dana Desa di Desa Linelean Kecamatan Modoinding Tahap I dan II tahun 2017

\begin{tabular}{ccccc}
\hline \multirow{2}{*}{ No } & Desa & Dana Desa & \multicolumn{2}{c}{ Pertanggungjawaban } \\
\cline { 3 - 4 } & & & Fisik & Keuangan \\
\hline 1. & Linelean & 754.555 .000 & $100 \%$ & Lengkap \\
\hline
\end{tabular}

Sumber : Pelaporan Dana Desa di Desa Linelean, 2018

Penggunaan Dana Desa. Penggunaan DD mengacu pada RPJMD dan RKPD. Menteri yang menangani Desa menetapkan fokus penggunaan Dana Desa paling lambat 2 (dua) bulan sebelum dimulainya tahun anggaran. Lembaga pemerintah nonkementrian menjadikan patokan umum aktivitas yang dibiayaai dari diputuskan selambat-lambatnya 2 bulan setelah ditetapkannya prioritas pembangunan dana desa.

Tabel 2. Hasil bidang pelaksanaan dan pembangunan desa di Desa Linelean Kecamatan Modoinding Kabupaten Minahasa Selatan yang dibangun Dengan DD tahun 2017

\begin{tabular}{lrlrl}
\hline No & Desa & \multicolumn{1}{c}{ Uraian } & Realisasi & Hasil \\
\hline 1 & Linelean & $\begin{array}{l}\text { Pekerjaan saluran drainase jaga 5 } \\
\text { dan jaga 6 }\end{array}$ & 208.031 .100 & Baik \\
& & $\begin{array}{l}\text { Pekerjaan saluran drainase jalan } \\
\text { kebun bandungan }\end{array}$ & 407.673 .900 & Baik \\
& Perawatan saluran air & 35.000 .000 & Baik \\
& & & 650.705 .000 \\
\hline
\end{tabular}

Sumber : Laporan Akhir Dana Desa di Desa Linelean

Tabel 3. Hasil bidang pemberdayaan masyarakat di Desa Linelean Kecamatan Modoinding Kabupaten Minahasa Selatan yang dibangun Dengan DD tahun 2017

\begin{tabular}{cclrc}
\hline No & Desa & \multicolumn{1}{c}{ Uraian } & Realisasi & Hasil \\
\hline 1 & Linelean & Bimtek Hukum Tua, Sekdes, & & \\
& & Bendahara Desa dan BPD & 50.000 .000 & Baik \\
& Pelatihan perencanaan partisipatif & 8.500 .000 & Baik \\
& Pelatihan BUMDES & 15.000 .000 & Baik \\
& Pelatihan kader Teknik & 2.500 .000 & Baik \\
& Pelatihan kelompok perempuan & 8.400 .000 & Baik \\
& Kegiatan posyandu & 4.450 .000 & Baik \\
& & & 88.850 .000 \\
\hline
\end{tabular}

Sumber : Kantor Desa Linelean

\subsection{Pembahasan}

Analisis Penyaluran Dana Desa di Desa Linelean Kecamatan Modoinding. Berdasarkan hasil penelitian yang ada di desa linelean kecamatan modoinding bahwa Penyaluran DD dilaksanakan melalui pemindahbukuan dari RKUN ke RKUD kemudian dari 
RKUD ke RKD. Menurut Peraturn Bupati Minahasa Selatan No 02 Tahun 2017 mengenai Tata Cara Pembagian dan Rincian DD seluruh desa Tahun Anggaran 2017. Penyaluran Dana Desa dilakukan melalui pemindahbukuan dari RKUD ke RKUDes, yang dilakukan paling lamah 7 hari setelah Dana Desa diterima di RKUD setelah persyaratan penyaluran terpenuhi.

Analisis Penggunaan Dana Desa Pada Desa Linelean Kecamatan Modoinding. Berdasarkan hasil penelitian yang ada pada Desa Linelean Kecamatan Modoinding bahwa DD digunakan untuk penyelenggaraan pemerintahan, pembangunan, pemberdayaan masyarakat, dan kemasyarakatan pada Desa Linelean Kecamatan Modoinding.

a. Pengembangan kapasitas, ketahanan dan informasi masyarakat Desa.

b. Pengelolaan kegiatan pelestarian lingkungan hidup.

c. Kesiapsiagaan menghadapi bencana alam serta penanganan kejadian luar biasa lainnya.

d. Dukungan pemodalan dan usaha produktif dan dikelolah BUMDes Bersama.

\section{KESIMPULAN DAN SARAN}

\subsection{Kesimpulan}

Berdasarkan hasil penelitian dan pembahasan yang telah dilakukan pada Desa Linelean Kecamatan Modoinding, maka dapat diambil kesimpulan sebagai berikut:

1. Proses penyaluran Dana Desa pada Desa Linelean Kecamatan Modoinding sudah di terima oleh Pemerintah Desa dari Pemerintah Pusat, yang di masukan kedalam APBDes. Pengelolaan Dana Desa di Desa Linelean Kecamatan Modoinding sudah mengacu pada Peraturan Bupati Minahasa Selatan Nomor 02 Tahun 2017 tentang Tata Cara Pembagian Dan Penetapan Rincian Dana Desa Setiap Desa Kabupaten Minahasa Selatan Tahun Anggaran 2017 Pasal 8 di jelaskan proses penyaluran Dana Desa dilakukan melalui 2 tahap yaitu Tahap I 60\% (enam puluh per seratus) dan Tahap II 40\% (empat puluh per seratus).

2. Pemerintah desa pada dasarnya berhak terhadap penggunaann $D$ sudah sesuai dengan prioritasnya yaitu untuk prmbangunan desa dan pemberdayaan masyarakat.

\subsection{Saran}

1. Mengingat laporan Pertanggungjawaban dana desa sangat penting dalam pengelolaan dana desa untuk itu agar lebih ditingkatkan lagi sumber daya manusia, pendidikan, dan pelatihan di desa dalam pengoperasian komputer.

2. Peran serta masyarakat di dalam pembangunan desa sangat penting sehingga pemerintah daerah berkewajiban memberikan pendekatan-pendekatan maupun sosialisasi terhadap masyarakat agar pembangunan didesa dapat terlaksana dengan baik.

\section{DAFTAR PUSTAKA}

Mulyadi, 2014. Sistem Akuntansi cetakan keempat. Salemba Empat. Jakarta

Mursyidi. 2013. Lingkungan Oprasional Organisasi Pemerintahan

Norwadian. 2013. Definisi Akuntansi Sektor Publik. Erlangga. Jakarta.

Peraturan Bupati Minahasa Selatan Nomor 02 Pasal 8 Tahun 2017 Tentang Penyaluran Dana Desa.

Riyanto. 2015. Definisi Akuntansi Pemerintahan.UGM, Yogyakarta

Siregar, 2015. Tujuan Akuntansi Sektor Publik. Erlangga. jakarta

Sujawerni, 2015. Definisi Akuntansi Sektor Publik. Yogyakarta

- Sistem Akuntansi. Pustaka baru press, Yogyakarta 